\title{
Giant renal oncocytoma with classic stellate scar
}

\author{
Rachael D Sussman, Keith J Kowalczyk
}

Department of Urology, MedStar Georgetown University Hospital, Washington, DC, USA

\section{Correspondence to} Dr Rachael D Sussman, sussman.rachael@gmail.com

Accepted 11 January 2017

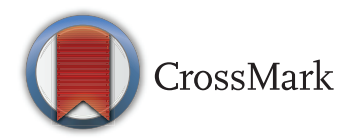

To cite: Sussman RD, Kowalczyk KJ. BMJ Case Rep Published online: [please include Day Month Year] doi:10.1136/bcr-2016218944

\section{DESCRIPTION}

A middle-aged man with poor access to medical care presented with shortness of breath and 3 years of abdominal distention. On physical examination, he was found to have a palpable mass in the left upper quadrant. He was found to have undiagnosed congestive heart failure with dilated cardiomyopathy, and a CT scan of the abdomen and pelvis revealed a left renal mass.

An MRI performed to further characterise the lesion demonstrated a large exophytic mass with a central scar and segmental enhancement originating from the lateral aspect of the left kidney with no evidence of renal vein or caval thrombus (figure 1). Owing to the possibility of renal malignancy, the patient underwent an open left radical nephrectomy through a hemi-chevron incision. The patient recovered well with no complications and was discharged home in good condition. Gross pathology demonstrated a $26 \mathrm{~cm}$ well-circumscribed mahogany brown tumour with intervening fibrous tissue and central scarring (figure 2). Histology was consistent with oncocytoma (figure 3). Immunohistochemical staining showed diffuse positivity for CD117 and E-cadherin, negativity for vimentin and only patchy positivity for CK7, all of which further supported the diagnosis.

Renal oncocytomas are the most common benign renal tumours accounting for $3-7 \%$ of kidney tumours. As demonstrated in this case, they typically appear as an enhancing renal mass on crosssectional imaging and are presumed to be renal cell carcinoma (RCC) until surgical excision. Common imaging characteristics include a central stellate scar with segmental enhancement, and a spoke-wheel pattern of feeding arteries. Unfortunately, imaging

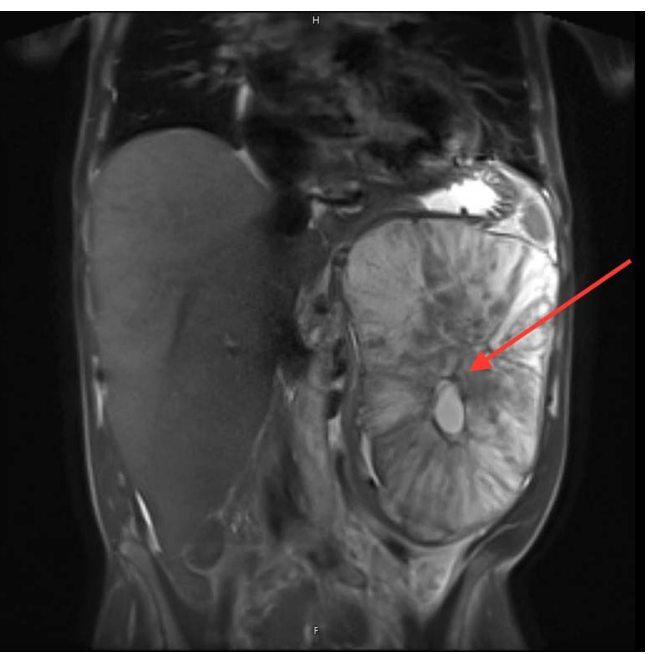

Figure $1 \mathrm{MRI}$ of left renal mass with central stellate scar (arrow) and segmental enhancement.

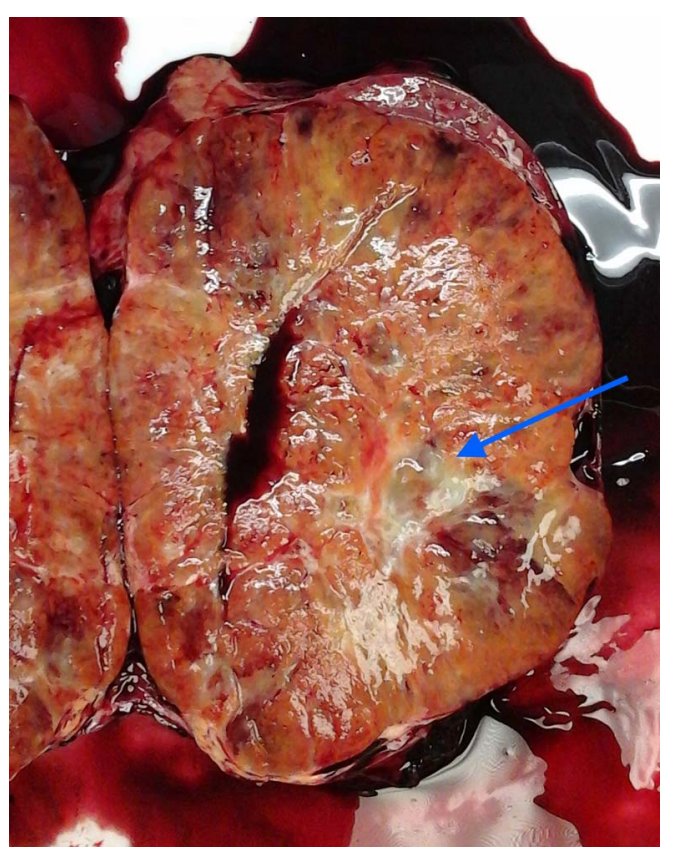

Figure 2 Gross pathology of bivalved renal oncocytoma showing intervening fibrous tissue and central scar (arrow).

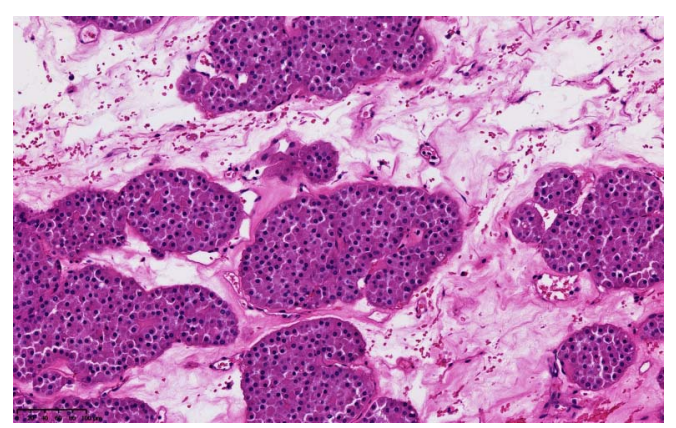

Figure 3 Histology demonstrating large eosinophilic cells arranged in distinct nests typical of oncocytoma.

characteristics cannot reliably distinguish benign renal oncocytomas from malignant lesions. ${ }^{1}$

Like RCC, oncocytomas develop from the intercalating cells of the collecting ducts. Microscopically, the cells of oncocytoma have intensely eosinophilic granular cytoplasm due to the abundance of mitochondria. As demonstrated in figure 3, the cells are typically large and uniform and arranged in a nested growth pattern. Histologically, oncocytomas present a dilemma, as they look very similar to chromophobe and clear cell RCC with eosinophilic characteristics. Immunohistochemical markers are often used to help distinguish the benign oncocytoma from malignant lesions such as clear cell and chromophobe RCC. Clear cell RCC most often stains positive for vimentin and negative for 
E-cadherin and CD 117, while oncocytoma and chromophobe RCC are most often positive for E-cadherin and CD117 and negative for vimentin. Strong CK 7 staining is found in most

\section{Learning points}

This represents the second largest oncocytoma ever reported in the literature.

- Giant oncocytomas, albeit rare, can still follow the classic pattern of stellate scar pathologically and radiologically.

- Immunohistochemical staining can be useful in distinguishing renal oncocytoma from malignant lesions such as clear cell and chromophobe renal cell cancer. chromophobe RCC, whereas it is most often negative in clear cell RCC and negative or focally weak oncocytoma. ${ }^{2}$

To the best of our knowledge, this case represents the second largest oncocytoma reported in the literature, with the largest reported oncocytoma measuring $27 \mathrm{~cm} .^{3}$

Contributors RDS and KJK involved in the care of the patient, imaging review and in the writing of this report.

Competing interests None declared.

Provenance and peer review Not commissioned; externally peer reviewed.

\section{REFERENCES}

1 Rosenkrantz $A B$, Hindman N, Fitzgerald $E F$, et al. MRI features of renal oncocytoma and chromophobe renal cell carcinoma. AJR AM J Roentgenol 2010;195:W421-7.

2 Zhou M, Roma A, Magi-Galluzzi C. The usefulness of immunohistochemical markers in the differential diagnosis of renal neoplasms. Clin Lab Med 2005:25:247-57.

3 Demos TC, Malone AJ Jr. Computed tomography of a giant renal oncocytoma. J Comput Assist Tomogr 1988;12:899-900.

Copyright 2017 BMJ Publishing Group. All rights reserved. For permission to reuse any of this content visit http://group.bmj.com/group/rights-licensing/permissions.

BMJ Case Report Fellows may re-use this article for personal use and teaching without any further permission.

Become a Fellow of BMJ Case Reports today and you can:

- Submit as many cases as you like

- Enjoy fast sympathetic peer review and rapid publication of accepted articles

- Access all the published articles

- Re-use any of the published material for personal use and teaching without further permission

For information on Institutional Fellowships contact consortiasales@bmjgroup.com

Visit casereports.bmj.com for more articles like this and to become a Fellow 